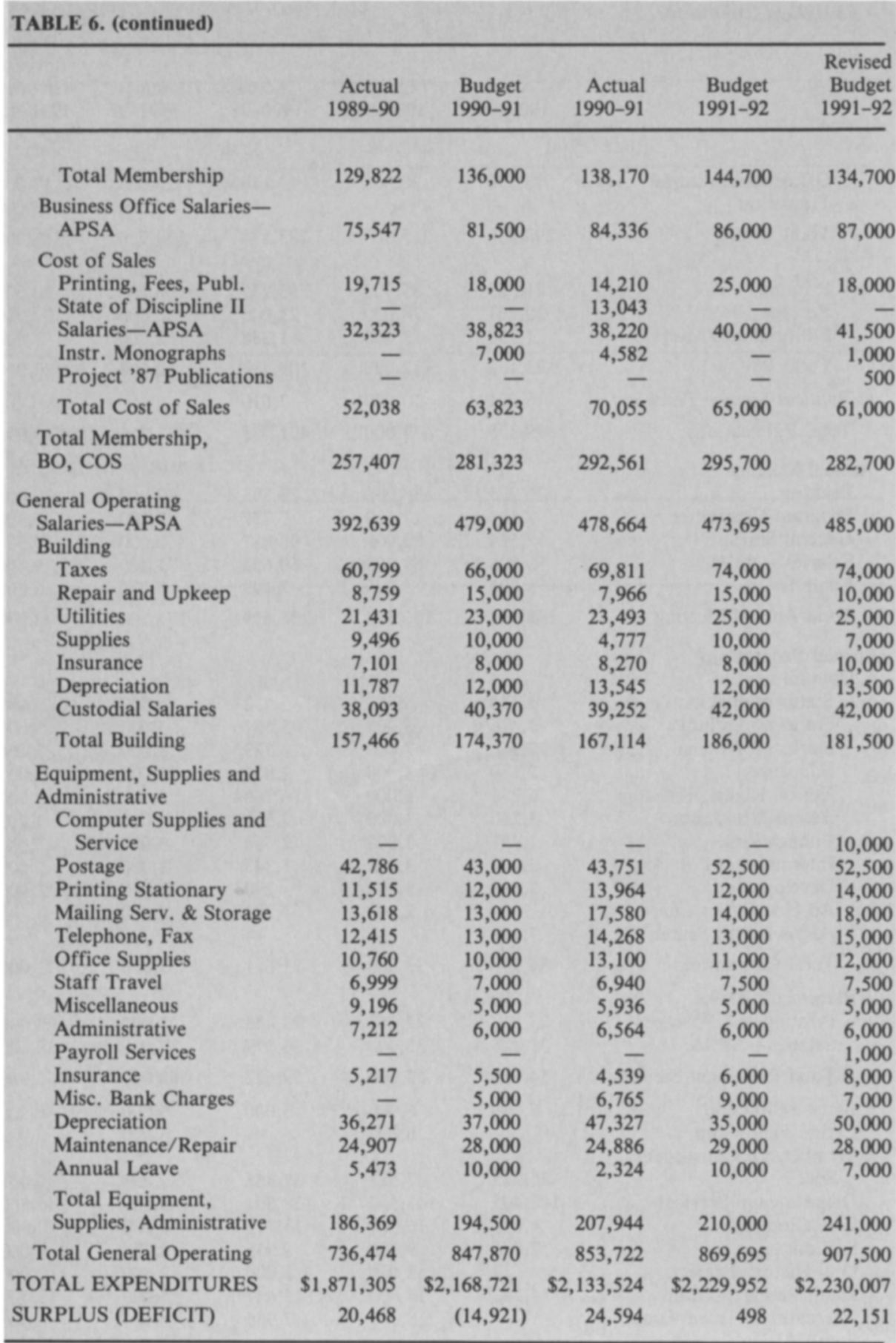

Department of Neurology, and Director, Section of Neuromuscular Diseases, University of Colorado Health Services Center, Denver

\section{American Anthropological Association Fellow}

David I. Beriss, Ph.D. Candidate in French Studies/Anthropology, New York University

\section{German Fellows}

Susanne R. Frischling, Ph.D. Candidate, Master's Degree in Political Science and Public International Law, Hamburg University

Gotz-Dietrich Opitz, Master's Degree in American Culture, Political Science and Communication, LudwigMaximilian University, Munich; Head Clerk, SPD Office, Constituency of Munich

\section{Asia Foundation Fellows}

Jackson Ke-Čheng Chang, Legislative Assistant, Legislative Yuan, Taipei, Taiwan

Hashjbatyn Hulan, Full-Time Consultant, Standing Committee on Social Policy, Baga Hural (Parliament, Ulan Bator, Mongolia

Thanong Khanthong, Assistant Business Editor, The Nation, Bangkok, Thailand

Maria Lourdes y Navarro Tiquia, Research Program Officer, Congressional Research and Training Service, Quezon City, Philippines

\section{Grants Awarded by The Bill of Rights Education Collaborative}

The Bill of Rights Education Collaborative, a joint program of the American Political Science Association and the American Historical Association, is supported by The Pew Charitable Trusts. Its goal is to strengthen pre-college education about constitutional rights by providing teachers with a range of collaborative professional activities. To this end, the program has awarded grants, on a competitive basis, to support these activities. A complete description of The Bill of Rights Education Collaborative was featured in PS: Political Science \& Politics, March 1991, pp. 104-06. Now, with the grant competitions concluded, lists of the grantees who are conducting short courses for teachers and the high school teachers who received mini grants for their own special projects follow.

\section{Short Courses}

The Bill of Rights and the States, Michael R. Zuckert, Carleton College.

Celebrating the Bill of Rights:

Civil Liberties at Home and Abroad, Jerome O'Callaghan, Texas Tech University.

Civil Rights and Civil Liberties Under the Bill of Rights, Henry S. Cohn and Denise Wright Merrill, Connecticut Consortium for LawRelated Education with the Univer- 
sity of Hartford's Museum of American Political Life.

The First Amendment, Religion and American Society, Mary Hepburn and Lief Carter, University of Georgia.

New Jersey and the Bill of Rights, Susan R. Schrepfer, Rutgers Center for Historical Analysis.

Teaching About First Amendment Freedoms, James J. Carroll, Syracuse University.

Constitutions in Comparative Perspective: The Protection of Rights in a Global Context, James J. Lorence, University of Wisconsin.

The Bill of Rights: Who Guarantees What to Whom, Danny Goble, Carl Albert Center and University of Oklahoma.

The Judiciary and the First Amendment, Melvin I. Urofsky, John Marshall Foundation.

Women, Minorities and Constitutional Rights: A Comparative Examination, Helen S. Ridley and Ann W. Ellis, Kennesaw State College.

The Bill of Rights: Teaching Its Origins and Ratification, John Drisko, National Center for America's Founding Documents, Boston University.

The Bill of Rights and the Japanese Internment Cases of World War II, Rosalyn Tonai, National Japanese American Historical Society.

Privacy, the Bill of Rights and American Life, James C. Foster, Oregon State University.

TABLE 7.

APSA National Office Salary Scale, 1991-92

\begin{tabular}{|c|c|c|c|c|c|c|}
\hline \multirow[b]{2}{*}{ APSA Position } & \multirow{2}{*}{$\begin{array}{l}\text { Equivalent } \\
\text { Government } \\
\text { Grade }\end{array}$} & \multirow{2}{*}{$\begin{array}{c}1991 \\
\text { Federal } \\
\text { Salary Scale }\end{array}$} & \multirow{2}{*}{$\begin{array}{c}1991-92 \\
\text { APSA } \\
\text { Grade }\end{array}$} & \multirow{2}{*}{$\begin{array}{c}1991-92 \\
\text { APSA } \\
\text { Salary Scale }\end{array}$} & \multicolumn{2}{|c|}{$\begin{array}{l}\text { Number of } \\
\text { Employees }\end{array}$} \\
\hline & & & & & FT & PT \\
\hline \multicolumn{7}{|l|}{ Political Scientists } \\
\hline Executive Director & $17-18$ & $83,032-97,317$ & 8 & $80,000-95,000$ & 1 & \\
\hline Deputy Director & $15-17$ & $61,643-94,104$ & 7 & $60,000-85,000$ & 1 & \\
\hline Program Directors & $13-15$ & $44,348-80,138$ & 6 & $40,000-75,000$ & 2 & 2 \\
\hline \multicolumn{7}{|l|}{ Non-Political Scientists } \\
\hline Program Coordinators & $11-12$ & $31,116-48,481$ & 5 & $30,000-40,000$ & 4 & \\
\hline Senior Admin. Asst. & $9-10$ & $25,717-36,818$ & 4 & $20,000-35,000$ & 4 & \\
\hline Administrative Assistant & 6-8 & $18,919-30,268$ & 3 & $18,000-30,000$ & 4 & \\
\hline \multicolumn{7}{|l|}{ Secretary, Receptionist, } \\
\hline Maintenance & 4-7 & $15,171-27,332$ & 2 & $15,000-27,000$ & 3 & \\
\hline Clerk & $1-3$ & $11,015-17,547$ & 1 & $11,000-17,000$ & 1 & 2 \\
\hline
\end{tabular}

Equal Protection in Wartime: Hirabayashi v. U.S., Margaret Armancas-Fisher, University of Puget Sound.

The Bill of Rights, the Courts and the Law, David Bearinger, Virginia Foundation for the Humanities.

The Bill of Rights in the Elementary Classroom, Michael Jacobson and Robert H. Lombard, Western Illinois University.

\section{Mini Grants}

Colleen Eickelman, Dorothy Turley and Rita Glass, McMillan Junior High School, Omaha, NE. Edward Duba, Canajoharie Central School, Canajoharie, NY.

Robert Reichel, Arsenal Technical
High School, Indianapolis, IN. Robert Allekotte, AMY-5 School, Philadelphia, PA.

William J. Allen, Cadillac Area

Public Schools, Cadillac, MI.

Barbara Altergott, Notre Dame de Sion School, Kansas City, MO.

Linda Atchley, Fisher Elementary

School, Oklahoma City, OK.

Stephani Bessell, Linda Johnson,

Robert Schmuck, Pompano MultiPurpose Education Center, Pompano, FL.

Jamie Teri Braden, Bingham Middle School, Broken Arrow, OK.

Lillie B. Brewer, Woodward Junior High School, North Wilkesboro, NC.

Glen Bryan, Bowlegs Public

Schools, Bowlegs, OK.

\begin{tabular}{|c|c|c|c|c|c|c|c|}
\hline \multirow[b]{2}{*}{ Security Type } & $\begin{array}{l}\text { RTFOLIO SL } \\
\text { Political Scie } \\
\text { st \& Developr } \\
\text { June 29, } 1\end{array}$ & $\begin{array}{l}\text { MMARY } \\
\text { ce Association } \\
\text { ent Fund } \\
90\end{array}$ & \multirow[b]{2}{*}{ Pct. Assets } & \multirow[b]{2}{*}{ Security Type } & $\begin{array}{l}\text { RTFOLIO SU } \\
\text { Political Scie } \\
\text { st \& Developr } \\
\text { June 30, } 1\end{array}$ & $\begin{array}{l}\text { MMARY } \\
\text { ice Association } \\
\text { ent Fund } \\
91\end{array}$ & \multirow[b]{2}{*}{ Pct. Asset: } \\
\hline & Cost Value & Market Value & & & Cost Value & Market Value & \\
\hline Equities & & & & Equities & & & \\
\hline Common Stock & 100,282 & 81,500 & 4.9 & Mutual Funds & & & \\
\hline \multirow[t]{2}{*}{ Mutual Funds } & 686,918 & $1,136,765$ & 69.0 & $\begin{array}{l}\text { Equity Funds } \\
\text { Bond Funds }\end{array}$ & $\begin{array}{l}501,873 \\
185,045 \\
\end{array}$ & $\begin{array}{r}961,165 \\
209,216 \\
\end{array}$ & $\begin{array}{l}49.5 \\
10.8 \\
\end{array}$ \\
\hline & 787,200 & $1,218,265$ & 73.9 & & 686,918 & $1,170,381$ & 60.3 \\
\hline Fixed Income & & & & Mixed Income & & & \\
\hline Corporate Bonds & 100,750 & 100,000 & 6.1 & GNMA & 35,989 & 40,549 & 2.1 \\
\hline Government Bonds & 26,813 & 25,422 & 1.5 & Certificates of Deposit & 5,000 & 5,000 & 0.3 \\
\hline GNMA & 41,141 & 46,039 & 2.8 & & & & \\
\hline Cash and Equivalents & & & & & 40,989 & 45,549 & 2.3 \\
\hline Cash and Equivalents & 258,634 & 258,634 & 15.7 & Cash and Equivalents & 726,375 & 726,375 & 37.4 \\
\hline TOTAL PORTFOLIO & $1,214,538$ & $1,648,360$ & 100.0 & TOTAL PORTFOLIO & $1,454,282$ & $1,942,304$ & 100.0 \\
\hline
\end{tabular}


Mary Kay Buckius, Campus Middle School, Englewood, CO.

Cathey Bugg and Cindy Koss, Summit Middle School, Edmond, OK.

D. J. Champagne, Van Horn

Engineering and Technology Magnet

High School, Independence, MO.

Connie Claborn, Boone School,

Apache, OK.

Charlotte Christenson and Ruby

E. Wanland, Miami Beach Senior

High School, Miami Beach, FL.

Stuart J. Davis, The Madeira

School, McLean, VA.

Cheryl Dean and Jean Lucas, West

Vigo High School, West Terre

Haute, IN.

Don R. Evans, North Side High

School, Fort Wayne, IN.

Cherylanne Farley, Foothill High

School, Bakersfield, CA.

Barbara L. S. Finch, Duchesne

Academy of the Sacred Heart,

Houston, TX.

Deena Kaye Music Fleck, Woodward High School, Woodward, OK.

Walter Fordham, Rogers Academy

of the Liberal Arts and Sciences,

Kansas City, MO.

Robert Gabrick, White Bear High

School, White Bear Lake, MN.

Gary W. Gallagher, West Junior

High School, Ponca City, OK.

David B. Green, Oldham County

High School, Buckner, KY.

Donna Marie Haines, The King's

Academy, West Palm Beach, FL.

Susan Hanson, Apple Valley

Christian School, Apple Valley, CA.

Delories E. Horton, M.A. Teasley

Middle School, Canton, GA.

Judith M. Jordan, McKinley Ele-

mentary School, Enid, OK.

Agatha Kelley and Ann Shurgin,

Wantagh Middle School, Wantagh,

NY.

Gerald P. Long, Brown County

High School, Nashville, IN.

Elaine Marsh, Odessa R-VII

School District, Odessa, MO.

Theresa Thornbury McDonald,

Astronaut High School, Titusville,

FL.

Micala McMurrian, McKinley

Senior High School, Baton Rouge,

LA.

Geraldine Milgroom, Maurice B.

Tobin School, Roxbury, MA.

Linda Karen Miller, Fairfax High

School, Fairfax, VA.

Barbara Morrison, Nova Alterna- tive High School, Seattle, WA.

Stefan Montovani, Newton High

School, Glendale, NY.

Bonnie L. Noonan, Hansen

School, Cedar Falls, IA.

Martha Ozturk, Champlain Valley

Union High School, Hinesburg, VT.

Thomas Parker, Phoenix Alterna-

tive High School, Holland, MI.

Rose Reissman, P.S. 169, Flush-

ing, NY.

Bettye C. Ricks, Ludlow School,

Philadelphia, PA.

Beverly Riggs and Karel K. Payne,

Stillwater Public Schools, Stillwater,

OK.

Robert Rowen, Alps View High

School, Weaverville, CA.

Peggy Scott, University High

School, Normal, IL.

David M. Seiter, Davis School

District, Layton, UT.

Gloria Sesso, Half Hollow Hills

High School, Dix Hills, NY.

Walter Franklin Shaw, Center

Mid-High School, Norman, OK.

Sr. Mary Adelaine Keehn, SND,

Notre Dame Academy, Los Angeles, CA.

JoAnn Cruzen Smith, Sequoyah

Middle School, Broken Arrow, OK.

John Ogle, Bokoshe Public

Schools, Bokoshe, OK.

Cathy Ann Stanford, Thomas

High School, Thomas, OK.

H. Mel Stark and Lorraine Loto-

wycz, Hillside School, Bridgewater,

NJ.

Les Steele, Okemah Public

Schools, Okemah, OK.

Jeannette Stern, Wantagh Middle

School, Wantagh, NY.

Joseph M. Sweeney, Joseph

Pulitzer IS 145, Jackson Heights,

NY.

Timothy J. Tuttle, Centennial

High School, Corona, CA.

Jeanne Vander Roest, Fabens

I.S.D., Fabens, TX.

Phillip M. Wasylean, Lawrence

High School, Lawrence, MA.

Mike Watson and Robin Hebert,

Anderson County High School,

Lawrenceburg, KY.

Bill Wilson, D.W. Daniel High

School, Central, SC.

Myron Yoder, L. E. Dieruff High

School, Allentown, PA.

Alan Haskvitz, Suzanne Middle

School, Walnut, CA.

Kevin P. Sheehan, Oceanside Mid-

dle School, Massapequa, NY.
APSA's Bunche Students Attend Annual Meeting

Eleven of the 25 students participating in the Ralph Bunche Summer Institute came to Washington, D.C. to attend APSA's Annual Meeting. The students were recognized at the reception given by the Committee on the Status of Blacks in the Profession.

The Bunche Institute is hosted by a consortium of five Atlanta institutions: Spelman College, Emory University, Morehouse College, Clark Atlanta University and Georgia State University. Each year 25 outstanding African American undergraduates are selected to attend the six-week program whose purpose is to encourage enrollment in graduate school. This year students from 17 states attended the Bunche Institute. Twelve of the 25 participants hailed from historically black colleges.

Students enroll in two courses, one in American politics and one in methodology. This summer the courses were taught by Jeanne Meadows of Spelman and Courtney Brown of Emory. The Institute is directed by Lois Moreland of Spelman College and is sustained by the volunteer efforts of Tobe Johnson of Morehouse, William Boone of Clark Atlanta, William Thomas of Georgia State, and Eleanor Main and Micheal Giles of Emory. In addition, many prominent political scientists give their time as guest lecturers, and over 40 graduate programs sent representatives to Atlanta to recruit the students for graduate school.

Funding for the Bunche Institute is generously provided by the CocaCola Foundation, the U.S. Department of Education, the Ford Foundation, the Graduate School of Emory University, and Georgia State University.

Application forms for the 1992 Ralph Bunche Summer Institute are available from APSA.

\section{Policy Studies Organization Presents 1991 Awards}

The following awards were presented by the Policy Studies Organi- 
zation at its August 30, 1991, awards dinner.

Richard Neustadt, Harold D. Lasswell Award for outstanding scholarship in contribution to our understanding of the substance or process of public policy.

Carol Weiss, Donald Campbell Award for being an outstanding methodological innovator in public studies.

Robert Wood, Hubert H. Humphrey Award for being an outstanding public policy practitioner.

John Gist, Theodore Lowi Award for the best article in the Policy Studies Journal in 1990.

Amitai Etzioni, Jeffrey Pressman Award for the best article in the Policy Studies Review in 1990.

Richard Tobin, PSO Book Award for the best policy studies book in 1990.

Stuart Nagel, Thomas R. Dye Award for outstanding service to the Policy Studies Organization.

William Crotty, PSO Presidents Award for service as a PSO president.

\section{New Section on Political Psychology Formed}

A new organized section on political psychology was approved by the APSA Council at the 1991 Annual Meeting. The section is intended to facilitate communication across subfields and disciplines among individuals interested in the relationship between political and psychological processes. The field is broadly conceived by the section to include qualitative and quantitative research on both international and domestic issues.

The Interim Executive Committee is comprised of Rick Lau, Rutgers University, Jerrold Post, George Washington University, and Sawn Rosenberg, University of California at Irvine. Maryanne Cusimano, Johns Hopkins University, is serving as Interim Chair and Program Chair. Dues are set at \$8. Contact APSA Membership Office to join the section, and Maryanne Cusimano,
Johns Hopkins University, Department of Political Science, Baltimore, MD 21218 for more information about participating.

\section{Call for Papers: 1992 Annual Meeting}

Paper proposals and offers to appear as discussants or panel chairs should be submitted as soon as possible. The deadline for receipt of submissions is December 1, 1991. Proposals for whole panels are welcome, but persons with suggestions for panels should get their requests in early.

Please write directly to the appropriate Program Committee section head listed below. More general inquiries or suggestions may be addressed to the Program Chair or to Jennifer Hacha, Convention Coordinator, APSA, 1527 New Hampshire Avenue, NW, Washington, DC 20036; (202) 483-2512.

Prospective participants should be aware of two APSA Council policies:

1. Acceptance of a proposal by the Program Committee obligates you to preregister (with appropriate fee) prior to June 1,1992 . If you fail to preregister, you will not be listed in the full program.

2. Participants may appear on two (but no more than two) panels in any capacity-chairing a panel, acting as discussant or presenting a paper. This rule applies to APSA Program Committee panels (including the Organized Section Panels) and Unaffiliated Group panels.

If you apply to several Program Committee sections, please inform each section leader that yours is a multiple application. Also, in that case, please notify the other section as soon as you have accepted an invitation for participation in another section. Proposals for papers should include author, title, and an abstract.

The 1992 Program will have no overarching theme although plenary sessions will be scheduled on the 1992 U.S. elections and on Europe 1992. Those interested in preparing panels or papers on teaching or curricular issues are advised to write to the section leader in the appropriate substantive area.

\section{Program Committee}

Program Chair: Thomas E. Mann, The Brookings Institution, 1775 Massachusetts Avenue, NW, Washington, DC 20036-2188; (202) 7976050; Fax: (202) 797-6004.

Political Thought and Philosophy: Historical Approaches. Stephen Holmes, Department of Political Science, University of Chicago, $5828 \mathrm{~S}$. University Avenue, Chicago, IL 60637; (312) 702-8050; Fax: (312) 702-0730.

Several topics will be of particular interest for the 1992 history of political theory panels.

First, the history of political psychology. The great political theorists, from Aristotle and the Stoics, through the 17th-century French moral psychologists, up to Hume, Mandeville, and Smith in the eighteenth century have all made subtle contributions to understanding the microfoundations of human irrationality. Given the inroads of rational choice theory in political science, historians of political theory can enrich current debates by focusing attention on the theories of passion-driven and irrational behavior crucial for most political thought before the nineteenth century. Consider, for example, Descartes's intriguing challenge to rational choice thinking: "man would be perfectly rational if he didn't have a body!"

Second, the left/right schema. From 1789 to 1989 , Western and (eventually) world politics has been organized according to a partisan spectrum stretching from "left" to "right." It has never been realistic to assume that all political positions could be located along a single spectrum. Nevertheless, the grip of the left/right scheme on political selfunderstanding has been enormous. Historians of political theory can contribute to an understanding of this anomaly. Partial explanations to be explored include the following: (1) the rise of mass democracy requires the simplification of political issues into binary choices, (2) the eighteenth-century philosophy of history 